\title{
Motile Actinomycetes: Actinosynnema pretiosum subsp. pretiosum sp. nov., subsp. nov., and Actinosynnema pretiosum subsp. auranticum subsp. nov.
}

\author{
TŌRU HASEGAWA, ${ }^{*}$ SEIICHI TANIDA, KAZUNORI HATANO, EIJI HIGASHIDE, AND MASAHIKO \\ YONEDA \\ Applied Microbiology Laboratories, Central Research Division, Takeda Chemical Industries, Ltd., Osaka \\ 532, Japan
}

Three strains of motile nocardioform actinomycetes were isolated from sedge blades. The characteristics of these isolates led us to assign them to the genus Actinosynnema. Accordingly, we propose the following new taxa of Actinosynnema: Actinosynnema pretiosum subsp. pretiosum sp. nov., subsp. nov., containing type strain C-15003(N-1) (= IFO $13726=$ FERM-P $3992=$ ATCC 31281) and strain C-14919(N-2001) (= IFO 13723 = FERM-P 3991 = ATCC 31280); and Actinosynnema pretiosum subsp. auranticum subsp. nov., with type strain C14482(N-1001) $(=$ IFO $13725=$ FERM-P $4130=$ ATCC 31309).

During a screening program for the detection of antibiotic producers among rarely occurring members of the order Actinomycetales Buchanan, three strains that characteristically form coremia and motile elements from their aerial and vegetative mycelia were isolated from sedge blades. Delayed fragmentation of vegetative mycelia in liquid culture, the meso-diaminopimelic acid contents of whole-cell hydrolysates, lysozyme resistance, and the guanine-plus-cytosine contents of the deoxyribonucleic acids, together with the comments on group III Nocardia in Bergey's Manual of Determinative Bacteriology, 8th ed. (16), originally led us to assign these strains to the genus Nocardia $(7,24-26)$. However, additional characterization demonstrating the absence of any mycolic acids (17), cell wall type III/C (12) (meso-diaminopimelic acid and no diagnostically important carbohydrates), a lack of sporangia, and the formation of motile elements indicated that these strains are members of the genus Actinosynnema (6). These strains are distinct from previously described species and are described here as members of a new species in the genus Actinosynnema.

\section{MATERIALS AND METHODS}

Bacterial strains. The following strains were used in this study: strain C-15003(N-1) ${ }^{\mathrm{T}}$ (type strain) (= Institute for Fermentation, Osaka, Japan [IFO] $13726^{\mathrm{T}}=$ Fermentation Research Institute, Agency of Science and Technology, Tanidabecho, Ibaragi, Japan [FERM-P] $3992^{\mathrm{T}}=$ American Type Culture Collection, Rockville, Md. [ATCC] 31281 ${ }^{\mathrm{T}}$ ); strain C$14482(\mathrm{~N}-1001)^{\mathrm{T}}\left(=\right.$ IFO $13725^{\mathrm{T}}=$ FERM-P $4130^{\mathrm{T}}=$ ATCC $\left.31309^{\mathrm{T}}\right)$; and strain C-14919(N-2001) (= IFO 13723 = FERM-P 3991 = ATCC 31280). These strains were isolated from the surfaces of blades of Carex species in Shiga Prefecture, Japan, in September 1975. Actinosynnema mirum Waksman Institute of Microbiology, Rutgers, The State University, Piscataway, N.J. (IMRU) 3971 (= ATCC 29888) was originally isolated from the surface of a blade of Carex $\mathrm{sp}$. in New Jersey in September 1976. Cells of each organism grown on yeast extract-malt extract agar (International Streptomyces Project [ISP] medium 2) at $28^{\circ} \mathrm{C}$ for 4 days were suspended in $40 \%(\mathrm{vol} / \mathrm{vol})$ glycerol and stored at $-20^{\circ} \mathrm{C}(24)$. These cell suspensions were used throughout this study.

Morphological characterizations. To observe coremia, a block was cut from tyrosine agar (ISP medium 7), on which coremia formed after 7 days at $30^{\circ} \mathrm{C}$. This specimen was examined on a glass slide under a light microscope.

The aerial and vegetative mycelia of the organisms grown on yeast extract-malt extract agar and tyrosine agar were examined directly under the microscope. The spore-bearing hyphae were studied by electron microscopy by the method of Lechevalier and Lechevalier (11). To observe motile spores from aerial mycelia, an agar block ( 2 by $2 \mathrm{~cm}$ ) of a sporulating culture was placed upside down on the surface of a microtiter tray (Tominaga Works, Ltd.) filled with tryptone-yeast extract-glucose (TYG) medium ( $10 \mathrm{~g}$ of tryptone [Difco Laboratories], $6 \mathrm{~g}$ of yeast extract, 10 $\mathrm{g}$ of glucose, $1,000 \mathrm{ml}$ of distilled water, $\mathrm{pH} \mathrm{7.0)}$ and incubated for $1 \mathrm{~h}$ at room temperature, when numerous motile spores were released. The culture broth was diluted with distilled water, gently deposited on Formvar-coated grids, and air dried. The specimens were shadowed with platinum-paladium and examined with a JEM T7S electron microscope. Motile elements from vegetative mycelia grown in TYG medium at $30^{\circ} \mathrm{C}$ for $48 \mathrm{~h}$ on a reciprocal shaker also were examined by electron microscopy.

Cultural and physiological characterizations. For cultural and physiological characterizations, the ISP me- 


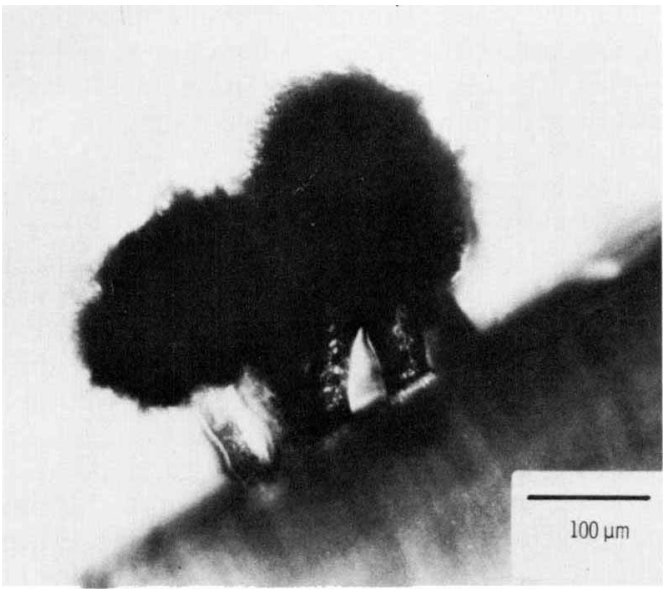

FIG. 1. Coremia of strain C-14919(N-2001).

dia recommended by Waksman (31) and endorsed by the ISP (21) were used. Cultures were incubated at $30^{\circ} \mathrm{C}$ and were observed after 7 and 14 days. Colors were compared with the colors in the Color Harmony Manual (8). Carbohydrate utilization was determined by the method of Pridham and Gottlieb (20). Temperature requirements for growth and fragmentation of vegetative mycelia were determined on yeast extractmalt extract agar and in TYG medium, respectively, with a model TN-3 temperature gradient incubator (Toyo Kagaku Sangyo Co. Ltd.). The effect of $\mathrm{pH}$ on growth was determined on yeast extract-malt extract agar at $30^{\circ} \mathrm{C}$. Other physiological tests (see Table 2) were carried out by the methods of Vera and Dumoff (30), Gordon et al. (5), Kesters and DeLey (9), and Arai and Mikami (1).

Cell analyses. Cell wall analysis was performed by the method of Becker et al. (2), and whole cells were analyzed by the procedure of Lechevalier (10). Fatty acids and mycolic acids were analyzed by the methods of Lechevalier et al. (13) and Minnikin et al. (17), respectively.

The procedures used for Gram staining and acid-fast staining were those described in the Manual of Clinical Microbiology, 2nd ed. (19).

Deoxyribonucleic acids were prepared by the method of Marmur (15) and were hydrolyzed by using perchloric acid. Guanine-plus-cytosine contents were determined by paper chromatography on Whatman no. 1 filter paper, using methanol-concentrated $\mathrm{HCl}$ water $(7: 2: 1, \mathrm{vol} / \mathrm{vol})$ as the developing solvent, followed by $0.1 \mathrm{~N} \mathrm{HCl}$ extraction.

Drug susceptibility. The susceptibilities of organisms to antimicrobial agents were tested by agar dilution on yeast extract-malt extract agar supplemented with streptomycin (Boehringer Co.), tetracycline [Lederle (Japan) Ltd.], chloramphenicol (Sankyo Co.), amphotericin B (PL Biochemicals Co.), and sulbenicillin (Takeda Chemical Industries, Ltd.).

\section{RESULTS AND DISCUSSION}

Strains C-15003(N-1) ${ }^{\mathrm{T}}, \mathrm{C}-14483(\mathrm{~N}-1001)^{\mathrm{T}}$, and C-14919(N-2001) are gram-positive, non-acid- fast, aerobic organisms with truly branching hyphae and therefore are placed in the order Actinomycetales Buchanan.

Morphology. On solid media strains C$15003(\mathrm{~N}-1)^{\mathrm{T}}, \mathrm{C}-14482(\mathrm{~N}-1001)^{\mathrm{T}}$, and $\mathrm{C}-14919(\mathrm{~N}-$ 2001) formed coremia similar in appearance to those of fungi, but they lacked sporangium formation. Inorganic salts-starch agar and tyrosine agar were suitable for the formation of coremia ( 50 to 200 by 200 to $1,500 \mu \mathrm{m}$ ) (Fig. 1). Aerial hyphae were formed at the tips of the coremia and on the surfaces of either domelike bodies or flat colonies. These hyphae became septate and gave rise to chains of spores. When observed with a transmission electron microscope, the mature hyphae (diameter, 0.5 to $1.2 \mu \mathrm{m}$ ) had a bamboo-like appearance (Fig. 2). Most of the spores with smooth surfaces were borne in chains and moved actively when incubated in TYG medium for $30 \mathrm{~min}$ at room temperature. The rod-shaped or ellipsoidal motile spores $(0.5$ to 1.2 by 1.0 to $2.0 \mu \mathrm{m}$ ) had peritrichous flagella about 4 to $4.6 \mu \mathrm{m}$ long (Fig. 3). After 6 or $7 \mathrm{~h}$ of incubation, several germ tubes were formed, and motility ceased.

The vegetative mycelia grown in TYG medium developed well, and after 42 to $66 \mathrm{~h}$ of cultivation at $30^{\circ} \mathrm{C}$, some of the hyphae (diameter, 0.5 to $1.2 \mu \mathrm{m}$ ) divided into rod-shaped, irregular or branching fragments, and a very few of the elements became motile. No satisfactory electron micrograph of these elements has been obtained.

A mutant that had a high fragmentation rate and lacked aerial mycelium (strain $\mathrm{N}$-1031) was derived from strain C-14482(N-1001) ${ }^{\mathrm{T}}$ by using $N$-methyl- $N^{\prime}$-nitro- $N$-nitrosoguanidine. When

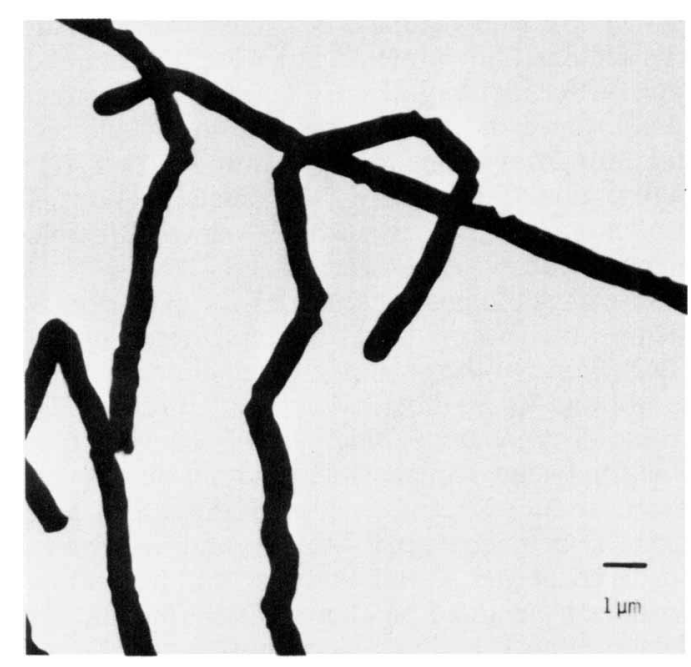

FIG. 2. Electron micrograph of spore chains from the tip of a coremium of strain C-14919(N-2001). 


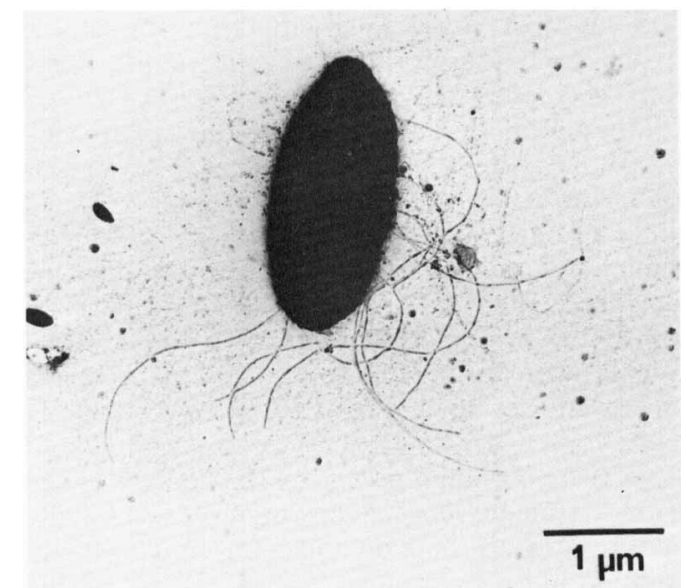

FIG. 3. Electron micrograph of a motile spore from aerial mycelium of strain $\mathrm{C}-15003(\mathrm{~N}-1)^{\mathrm{T}}$.

this mutant was incubated in TYG medium, most of the vegetative mycelia fragmented into rod-shaped elements ( 0.6 to 0.8 by 4.0 to $4.5 \mu \mathrm{m}$ ) with peritrichous flagella 9 to $11 \mu \mathrm{m}$ long (Fig. 4) at $30^{\circ} \mathrm{C}$ after $30 \mathrm{~h}$ of cultivation. The motile elements of strain N-1031 were morphologically similar to those of the parent strain.

Cultural and physiological characteristics. The colonial characteristics of the organisms studied on various media are shown in Table 1 . In general, these organisms grew better on organic media than on synthetic media. The vegetative growth of strains C- $15003(\mathrm{~N}-1)^{\mathrm{T}}$ and C-14919(N2001) was pale yellow to pale orangish yellow, whereas that of strain $\mathrm{C}-14482(\mathrm{~N}-1001)^{\mathrm{T}}$ was distinctively yellow to orange. The aerial mycelia were white to pale yellow. The mycelia formed on rich media (i.e., yeast extract-malt extract agar and oatmeal agar) were not retained long. After incubation at $30^{\circ} \mathrm{C}$ for about 7 days, the surfaces of colonies became moist and acquired a glossy appearance. Strains C-14482(N$1001)^{\mathrm{T}}$ and $\mathrm{C}-15003(\mathrm{~N}-1)^{\mathrm{T}}$ produced yellowish brown (camel [3ie]) to purplish brown diffusible pigments on tyrosine agar.

The physiological characteristics of the organisms which we studied are summarized in Table 2. None of the strains grew under anaerobic conditions when the GasPak system (BBL Microbiology Systems) was used. Growth took place between 12 and $38^{\circ} \mathrm{C}$, and aerial mycelia were produced between 20 and $35^{\circ} \mathrm{C}$. The best growth occurred at $\mathrm{pH} 7$ to 7.5 , and no growth occurred at $\mathrm{pH} 4$ and 9 . None of the strains produced melanoid pigments on ISP media, but they produced melanoid pigments when dioxyphenylalanine was used as the substrate. This indicates a lack of tyrosinase activity, which oxidizes tyrosine to dioxyphenylalanine and is indispensable for the formation of melanoid pigments. The strains grew well in lysozyme broth, but no growth occurred on media supplemented with $5 \% \mathrm{NaCl}$.

The proportion of viable cells was reduced to 1 in 100 by heating at $80^{\circ} \mathrm{C}$ for $5 \mathrm{~min}$. When 1 drop of $\mathrm{CHCl}_{3}$ was added to $1 \mathrm{ml}$ of the cell suspension, the proportion of viable ceils was reduced immediately to less than 1 in 10,000 .

Cell analyses. The cell analyses in this study gave very similar results for all of the organisms. The major amino acids and sugar in the cell walls were meso-diaminopimelic acid, glutamic acid, alanine, and galactose. Small amounts of lysine and glycine were detected, but arabinose was absent (cell wall type III [22]). In whole-cell hydrolysates madurose was not detected. The lipids contained straight- and branched-chain fatty acids, and a major component was a $\mathrm{C}_{17}$ acid (margaric acid) (Table 3). However, 10methyloctadecanoic acid (tuberculostearic acid) and mycolic acids were not detected.

The deoxyribonucleic acids of all of the organisms contained $71 \pm 1 \mathrm{~mol} \%$ guanine plus cytosine.

Young mycelia grown under submerged conditions were gram positive and not acid fast.

Among the actinomycetes with type III cell walls, Actinosynnema, Dermatophilus (4), Geodermatophilus (14), Planobispora (28), Planomonospora (29), and Spirillospora (3) are known to produce motile elements. Among these, Planomonospora, Planobispora, and Spirillospora form sporangia and contain madurose in wholecell hydrolysates. The members of the genera Dermatophilus and Geodermatophilus do not form aerial mycelia and produce motile cocci by division of hyphae. As far as we know, there has been no report of any actinomycete species that simultaneously produces different kinds of motile elements from aerial and vegetative mycelia.

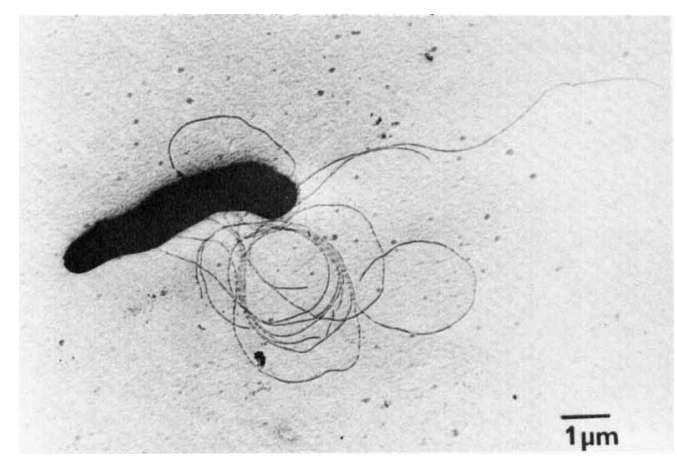

FIG. 4. Electron micrograph of a motile element from the vegetative mycelium of mutant strain $\mathrm{N}-1031$, which was derived from strain $\mathrm{C}-14482(\mathrm{~N}-1001)^{\mathrm{T}}$. 
TABLE 1. Characteristics of surface colonies of strains C-15003(N-1) ${ }^{\mathrm{T}}, \mathrm{C}-14482(\mathrm{~N}-1001)^{\mathrm{T}}$, and C-14919(N2001)

\begin{tabular}{|c|c|c|c|c|}
\hline Medium & $\begin{array}{l}\text { Culture } \\
\text { compo- } \\
\text { nent }^{a}\end{array}$ & Strain C-15003(N-1) ${ }^{\mathrm{T}}$ & Strain C-14482(N-1001) ${ }^{\mathrm{T}}$ & Strain C-14919(N-2001) \\
\hline \multirow[t]{3}{*}{$\begin{array}{l}\text { Sucrose-nitrate agar } \\
\quad(\text { Waksman medium } 1)\end{array}$} & $\mathrm{G}$ & $\begin{array}{l}\text { Moderate, bright melon } \\
\text { yellow (3ia) to amber } \\
\text { (31c) }\end{array}$ & Poor, thin, colorless & $\begin{array}{l}\text { Poor, colorless to light } \\
\text { yellow }\end{array}$ \\
\hline & A & Scant, white & Sparse, white & None \\
\hline & SP & $\begin{array}{l}\text { None or pale yellowish } \\
\tan \end{array}$ & None & None \\
\hline \multirow[t]{3}{*}{$\begin{array}{l}\text { Glucose-asparagine agar } \\
\text { (Waksman medium 2) }\end{array}$} & G & $\begin{array}{l}\text { Moderate, bright } \\
\text { marigold ( } 3 \mathrm{pa}) \text { to } \\
\text { bright yellow ( } 2 \mathrm{pa})\end{array}$ & $\begin{array}{l}\text { Moderate, colorless to } \\
\text { melon yellow (3ga) }\end{array}$ & $\begin{array}{c}\text { Moderate, colorless to } \\
\text { bright yellow (3na) }\end{array}$ \\
\hline & A & Scant, white & $\begin{array}{l}\text { Sparse, light melon } \\
\text { yellow (3ea) }\end{array}$ & $\begin{array}{l}\text { Scant, white to light } \\
\text { ivory (2ca) }\end{array}$ \\
\hline & SP & Bright yellow (2pa) & None & None \\
\hline \multirow[t]{3}{*}{$\begin{array}{l}\text { Glycerol-asparagine agar } \\
\text { (ISP medium 5) }\end{array}$} & $\mathrm{G}$ & $\begin{array}{l}\text { Moderate, light ivory } \\
\text { (2ca) }\end{array}$ & $\begin{array}{l}\text { Moderate, white to } \\
\text { melon yellow (3ga) }\end{array}$ & $\begin{array}{l}\text { Moderate, white to } \\
\text { yellow }\end{array}$ \\
\hline & A & Scant, white & $\begin{array}{l}\text { Moderate, white to } \\
\text { light wheat ( } 2 \text { ea) }\end{array}$ & Scant, light ivory (2ca) \\
\hline & SP & None & None & None \\
\hline \multirow[t]{3}{*}{$\begin{array}{l}\text { Inorganic salts-starch } \\
\text { agar (ISP medium 4) }\end{array}$} & G & $\begin{array}{l}\text { Moderate, light ivory } \\
\text { (2ca) to light wheat } \\
\text { (2ea) }\end{array}$ & $\begin{array}{l}\text { Moderate, colorless to } \\
\text { melon yellow ( } 3 \text { ga) or } \\
\text { colonial yellow maize } \\
(2 \mathrm{ga})\end{array}$ & $\begin{array}{l}\text { Moderate, light ivory } \\
\text { (2ca) to light wheat } \\
\text { (2ea) }\end{array}$ \\
\hline & A & $\begin{array}{l}\text { Abundant, light ivory } \\
\text { (2ca) }\end{array}$ & $\begin{array}{l}\text { Sparse, light to melon } \\
\text { yellow (2ea) }\end{array}$ & $\begin{array}{l}\text { Abundant, light ivory } \\
\text { (2ca) }\end{array}$ \\
\hline & SP & None & None & None \\
\hline \multirow[t]{3}{*}{$\begin{array}{l}\text { Calcium malate agar } \\
\quad(\text { Waksman medium } 7)\end{array}$} & G & $\begin{array}{l}\text { Moderate, light ivory } \\
\text { (2ca) to light wheat } \\
\text { (2ea) }\end{array}$ & $\begin{array}{l}\text { Moderate, colorless to } \\
\text { melon yellow ( } 3 \mathrm{ga}) \text { or } \\
\text { bright marigold ( } 3 \mathrm{pa})\end{array}$ & $\begin{array}{l}\text { Moderate, light yellow } \\
\text { to colonial yellow } \\
(2 \mathrm{ga})\end{array}$ \\
\hline & A & $\begin{array}{l}\text { Moderate, white to } \\
\text { light ivory (2ca) }\end{array}$ & Sparse, white & $\begin{array}{l}\text { Moderate, light yellow } \\
\text { to yellow }\end{array}$ \\
\hline & SP & None & None & None \\
\hline \multirow[t]{3}{*}{$\begin{array}{l}\text { Peptone-yeast extract } \\
\text { agar (ISP medium 6) }\end{array}$} & $\mathrm{G}$ & $\begin{array}{l}\text { Moderate, colonial } \\
\text { yellow ( } 2 \mathrm{ga})\end{array}$ & $\begin{array}{l}\text { Moderate, colorless to } \\
\text { beige brown (3ig) or } \\
\text { bright maize (31a) }\end{array}$ & $\begin{array}{l}\text { Moderate, light yellow } \\
\text { tan to light orange } \\
\text { yellow }\end{array}$ \\
\hline & A & None & None or sparse, white & None \\
\hline & SP & Colonial yellow (2ga) & Pale yellowish brown & None \\
\hline \multirow[t]{3}{*}{$\begin{array}{l}\text { Tyrosine agar (ISP } \\
\text { medium 7) }\end{array}$} & G & $\begin{array}{l}\text { Moderate, light ivory } \\
\text { (2ca) or ivory (2ca) to } \\
\text { light melon yellow } \\
\text { (3ea) }\end{array}$ & $\begin{array}{l}\text { Moderate, colorless to } \\
\text { beige brown (3ig) or } \\
\text { bright maize (31a) }\end{array}$ & Moderate, amber (3ic) \\
\hline & A & $\begin{array}{l}\text { Moderate, white to } \\
\text { light ivory (2ca) }\end{array}$ & $\begin{array}{l}\text { Sparse, pearl pink (3ca) } \\
\text { or bright maize (31a) }\end{array}$ & Scant, light yellow \\
\hline & SP & Camel (3ia) & $\begin{array}{l}\text { Light yellowish brown } \\
\text { with a tinge of purple }\end{array}$ & None \\
\hline \multirow[t]{3}{*}{$\begin{array}{l}\text { Nutrient agar (Waksman } \\
\text { medium 14) }\end{array}$} & G & $\begin{array}{l}\text { Moderate, light ivory } \\
\text { (2ca) to colonial } \\
\text { yellow (2ga) }\end{array}$ & $\begin{array}{l}\text { Moderate, colorless to } \\
\text { melon yellow ( } 3 \mathrm{ga}) \text { or } \\
\text { bright marigold (3pa) }\end{array}$ & Moderate, amber (3nc) \\
\hline & A & Scant, white & None & $\begin{array}{l}\text { Moderate, white to } \\
\text { pearl pink }\end{array}$ \\
\hline & SP & None & None & None \\
\hline $\begin{array}{l}\text { Yeast extract-malt } \\
\text { extract agar (ISP } \\
\text { medium 2) }\end{array}$ & G & $\begin{array}{l}\text { Moderate, amber (31c) } \\
\text { to bright yellow (31a) }\end{array}$ & $\begin{array}{l}\text { Luxuriant, colorless to } \\
\text { melon yellow (3ga) or } \\
\text { bright maize (31c) }\end{array}$ & Moderate, amber (3nc) \\
\hline
\end{tabular}


TABLE 1. Continued

\begin{tabular}{|c|c|c|c|c|}
\hline Medium & $\begin{array}{l}\text { Culture } \\
\text { compo- } \\
\text { nent }^{a}\end{array}$ & Strain C-15003(N-1) ${ }^{\mathrm{T}}$ & Strain C-14482(N-1001) $)^{\mathrm{T}}$ & Strain C-14919(N-2001) \\
\hline & A & $\begin{array}{l}\text { Moderate, white to } \\
\text { light ivory (2ca) }\end{array}$ & $\begin{array}{l}\text { Moderate, white to } \\
\text { pearl pink (3ca) or } \\
\text { light melon yellow } \\
\text { (3ea) }\end{array}$ & Moderate, white \\
\hline & SP & None & Pale yellowish brown & None \\
\hline \multirow[t]{3}{*}{$\begin{array}{l}\text { Oatmeal agar (ISP } \\
\text { medium 3) }\end{array}$} & $\mathrm{G}$ & $\begin{array}{l}\text { Moderate, light ivory } \\
\text { (2ca) to colonial } \\
\text { yellow ( } 2 \mathrm{ga})\end{array}$ & $\begin{array}{l}\text { Moderate, colorless to } \\
\text { melon yellow (3ga) or } \\
\text { colonial yellow maize } \\
(2 \mathrm{ga})\end{array}$ & $\begin{array}{l}\text { Moderate, amber ( } 3 \mathrm{nc}) \\
\text { to bright yellow (3na) }\end{array}$ \\
\hline & A & $\begin{array}{l}\text { Scant, white to light } \\
\text { yellow }\end{array}$ & $\begin{array}{l}\text { Moderate, white to } \\
\text { melon yellow (3ea) or } \\
\text { pearl pink ( } 3 \mathrm{ca})\end{array}$ & Moderate, light yellow \\
\hline & SP & None & $\begin{array}{l}\text { None or pale yellowish } \\
\text { brown }\end{array}$ & None \\
\hline
\end{tabular}

${ }^{a} \mathrm{G}$, Growth; A, aerial mycelium; SP, soluble pigment.

Except for the motile elements originating from the vegetative mycelium, the strains which we studied were most similar to species of the genus Actinosynnema. Therefore, we made a direct comparison between our three strains and $A$. mirum strain IMRU 3971. The characters which distinguish our strains from strain IMRU 3971 are listed in Tables 2 and 4 . Our three strains differed from $A$. mirum in gross appearance of the colonies, fragmentation of the vegetative mycelium, and production of both motile spores and motile mycelium fragments.

These differences indicate that strains $\mathrm{C}$ $15003(\mathrm{~N}-1)^{\mathrm{T}}, \mathrm{C}-14482(\mathrm{~N}-1001)^{\mathrm{T}}$, and C-14919(N2001) are members of a distinct species. Differences between two of the strains [C-15003(N-1) ${ }^{\mathrm{T}}$ and $\left.\mathrm{C}-14482(\mathrm{~N}-1001)^{\mathrm{T}}\right]$ and the other strain [C14919(N-2001)] indicate that there are two subspecies of the new species, for which we propose the names and descriptions given below. The characteristics listed below are those of all three strains unless otherwise indicated.

Actinosynnema pretiosum subsp. pretiosum sp. nov., subsp. nov. (pre. ti. o śum, L. adj. pretiosum precious).

Cell morphology. Branched vegetative hyphae are formed on various agar media. Some of the branched mycelia that are formed at a later stage of growth in liquid culture break up into motile elements with peritrichous flagella. Long, straight, helical, or, rarely, branching hyphae are white to pale yellow and about 0.5 to $1.2 \mu \mathrm{m}$

TABLE 2. Physiological and biochemical characteristics of $A$. pretiosum $\mathrm{C}-15003(\mathrm{~N}-1)^{\mathrm{T}}, \mathrm{C}-14482(\mathrm{~N}-1001)^{\mathrm{T}}$, and $C-14919(\mathrm{~N}-2001)$ and $A$. mirum $3971^{a}$

\begin{tabular}{|c|c|c|c|c|c|c|c|c|c|c|c|c|}
\hline \multirow{2}{*}{ Strain } & \multicolumn{2}{|c|}{\begin{tabular}{|c|} 
Temp range $\left({ }^{\circ} \mathrm{C}\right)$ \\
for:
\end{tabular}} & \multirow{2}{*}{$\begin{array}{l}\text { Hydrolysis } \\
\text { of gelatin }\end{array}$} & \multicolumn{8}{|c|}{ Utilization as sole carbon source } & \multirow{2}{*}{ Antagonist(s) } \\
\hline & Growth & $\begin{array}{l}\text { Optimum } \\
\text { growth }\end{array}$ & & $\begin{array}{c}\text { Arabi- } \\
\text { nose }\end{array}$ & $\begin{array}{l}\text { Lac- } \\
\text { tose }\end{array}$ & $\begin{array}{l}\text { Mal- } \\
\text { tose }\end{array}$ & $\begin{array}{l}\text { Rham- } \\
\text { nose }\end{array}$ & $\begin{array}{l}\text { Meli- } \\
\text { biose }\end{array}$ & $\begin{array}{c}\text { Raffi- } \\
\text { nose }\end{array}$ & $\begin{array}{c}\text { Glyc- } \\
\text { erol }\end{array}$ & $\begin{array}{c}\text { Soluble } \\
\text { starch }\end{array}$ & \\
\hline $\mathrm{C}-15003(\mathrm{~N}-1)^{\mathrm{T}}$ & $12-38$ & $29-32$ & \pm & + & - & \pm & + & + & \pm & - & + & $\begin{array}{l}\text { Ansamitocins }(7, \\
24), \text { tomaymycin } \\
(23)^{b}\end{array}$ \\
\hline C-14482(N-1001) ${ }^{\mathrm{T}}$ & $12-38$ & $24-32$ & \pm & - & \pm & + & + & \pm & \pm & + & + & $\begin{array}{l}\text { Dnacins (26) } \\
\quad \text { ansamitocins (27) }\end{array}$ \\
\hline C-14919(N-2001) & $12-38$ & $26-32$ & \pm & - & \pm & \pm & \pm & + & \pm & + & + & Macbecins $(18,25)$ \\
\hline IMRU 3971 & $10-35$ & $26-32$ & + & \pm & - & + & + & - & - & + & \pm & $\begin{array}{l}\text { Antibacterial and } \\
\text { antifungal } \\
\text { antibiotics (6) }\end{array}$ \\
\hline
\end{tabular}

${ }^{a}$ All four strains gave positive reactions in the following tests: peptonization of milk; hydrolysis of casein, starch, esculin, and tyrosine; utilization of xylose, glucose, fructose, galactose, mannose, sucrose, and trehalose as sole carbon sources; tolerance to $2 \% \mathrm{NaCl}$; and resistance to $100 \mu \mathrm{g}$ of amphotericin B per ml and $100 \mu \mathrm{g}$ of sulbenicillin per $\mathrm{ml}$. All strains gave negative reactions in the following tests: coagulation of milk; hydrolysis of urea, xanthine, and hypoxanthine; utilization of sorbitol or inositol as a sole carbon source; production of $\mathrm{H}_{2} \mathrm{~S}$; and resistance to $20 \mu \mathrm{g}$ of streptomycin per $\mathrm{ml}, 20 \mu \mathrm{g}$ of tetracycline per ml, or $20 \mu \mathrm{g}$ of chloramphenicol per ml. - , Negative response; \pm , doubtful response; + , positive response.

${ }^{b}$ Numbers in parentheses are references. 
TABLE 3. Fatty acid compositions of strains C-15003(N-1) ${ }^{\mathrm{T}}, \mathrm{C}-14482(\mathrm{~N}-1001)^{\mathrm{T}}$, and $\mathrm{C}-14919(\mathrm{~N}-2001)$

\begin{tabular}{|c|c|c|c|c|}
\hline \multirow[b]{2}{*}{ Fatty acid } & \multirow{2}{*}{$\begin{array}{l}\text { Retention time } \\
(\min )^{a}\end{array}$} & \multicolumn{3}{|c|}{ Peak area $(\%)$ in: } \\
\hline & & $\begin{array}{c}\text { Strain } \\
\mathrm{C}-15003(\mathrm{~N}-1)^{\mathrm{T}}\end{array}$ & $\begin{array}{c}\text { Strain } \\
\mathrm{C}-14482(\mathrm{~N}-1001)^{\mathrm{T}}\end{array}$ & $\begin{array}{c}\text { Strain } \\
\text { C-14919(N-2001) }\end{array}$ \\
\hline $12: 0$ & 0.35 & $<2.00$ & 3.45 & $<2.00$ \\
\hline 13:0 & 0.55 & 5.82 & 3.96 & 17.00 \\
\hline iso- $14: 0$ & 0.80 & $<2.00$ & 2.15 & 7.60 \\
\hline anteiso-15:0 & 1.25 & 5.46 & 3.19 & 13.30 \\
\hline $15: 0$ & 1.45 & 5.08 & 3.79 & 15.30 \\
\hline iso-16:0 & 1.80 & 5.46 & 9.65 & 17.00 \\
\hline $16: 0$ & 2.10 & 10.90 & 8.27 & 10.80 \\
\hline anteiso-17:0 & 2.75 & 12.60 & 10.59 & 7.90 \\
\hline $17: 0$ & 3.15 & 24.60 & 38.20 & 25.50 \\
\hline Unknown fatty acid & 4.00 & 8.90 & 6.98 & 3.98 \\
\hline $18: 0$ & 4.70 & 6.90 & 7.23 & 9.96 \\
\hline
\end{tabular}

${ }^{a}$ Samples were analyzed on Chromosorb W (80 to 100 mesh; AW-DMCS) by using 5\% OV-17 as the liquid phase in the column $(3 \mathrm{~mm}$ [inner diameter] by $1 \mathrm{~m})$. The following temperatures were used: $\operatorname{detector,~} 255^{\circ} \mathrm{C}$; injector, $270^{\circ} \mathrm{C}$; oven, $185^{\circ} \mathrm{C}$. The carrier gas was nitrogen, and the flow rate was $60 \mathrm{ml} / \mathrm{min}$.

in diameter. Hyphae are formed with tufts at the tips of the coremia on the surfaces of domelike or other extremely variable bodies. Aerial mycelia have a bamboo-like appearance, and septa are set down along these hyphae and give rise to chains of spores that are capable of moving with peritrichous flagella in an aqueous environment. The spore surface is smooth.

Colony morphology. Colonies on synthetic media are pale yellow to pale orange, convex, thin, slightly wrinkled, and spreading with a translucent edge; on organic media colonies are pale yellow to pale orange and wrinkled or leathery.

Growth conditions. No growth takes place under anaerobic conditions. Growth occurs between 12 and $38^{\circ} \mathrm{C}$ and between $\mathrm{pH} 6$ and $\mathrm{pH}$ 8.5 .

Cell composition. meso-Diaminopimelic acid, glutamic acid, alanine, lysine, glycine, and galactose are present, but arabinose is not. The cell walls are type III cell walls. The major fatty acid component is a $\mathrm{C}_{17}$ acid (margaric acid). Mycolic acids have not been detected.
Physiological and biochemical characteristics. Casein, tyrosine, starch, and esculin are hydrolyzed, but urea, xanthine, and hypoxanthine are not. Milk is peptonized. Nitrate reductase, alkaline phosphatase, and catalase are produced, but $\mathrm{H}_{2} \mathrm{~S}$ is not. Xylose, arabinose, glucose, galactose, mannose, sucrose, rhamnose, melibiose, trehalose, mannitol, and soluble starch are utilized as carbon sources for growth, but little or no growth is obtained with lactose, maltose, raffinose, sorbitol, inositol, and glycerol. Growth occurs on $2 \% \mathrm{NaCl}$ or in lysozyme broth.

Susceptibilities. This organism grows in the presence of $100 \mu \mathrm{g}$ of amphotericin B per $\mathrm{ml}$ and $100 \mu \mathrm{g}$ of sulbenicillin per ml. Streptomycin, tetracycline and chloramphenicol at concentrations of $20 \mu \mathrm{g} / \mathrm{ml}$ completely inhibit growth.

Source. The type strain was isolated from a blade of Carex species in Shiga Prefecture, Japan, in September 1975.

Antagonistic products. Produces ansamitocins $(7,24)$ and tomaymycin (23).

Guanine-plus-cytosine content of the deoxyri-

TABLE 4. Characteristics that distinguish strains $C-15003(\mathrm{~N}-1)^{\mathrm{T}}$, C-14482(N-1001) ${ }^{\mathrm{T}}$, and $\mathrm{C}-14919(2001)$ from A. mirum IMRU 3971

\begin{tabular}{|c|c|c|c|c|}
\hline \multirow[b]{2}{*}{ Strain } & \multicolumn{3}{|c|}{ Texture on: } & \multirow{2}{*}{$\begin{array}{l}\text { Fragmentation of } \\
\text { vegetative mycelia } \\
\text { in liquid media }\end{array}$} \\
\hline & $\begin{array}{l}\text { Tryptone-yeast extract } \\
\text { agar (ISP medium } 1 \\
\text { containing agar) }\end{array}$ & $\begin{array}{l}\text { Peptone-yeast extract- } \\
\text { iron agar (ISP medium 6) }\end{array}$ & $\begin{array}{l}\text { Tyrosine agar } \\
\text { (ISP medium 7) }\end{array}$ & \\
\hline $\mathrm{C}-15003(\mathrm{~N}-1)^{\mathrm{T}}$ & Convex, thin, spreading & $\begin{array}{l}\text { Convex, thin, slightly } \\
\text { wrinkled, spreading }\end{array}$ & $\begin{array}{l}\text { Convex, thin, slightly } \\
\text { wrinkled, spreading }\end{array}$ & Positive \\
\hline $\mathrm{C}-14482(\mathrm{~N}-1001)^{\mathrm{T}}$ & $\begin{array}{l}\text { Convex, slightly } \\
\text { wrinkled, leathery, } \\
\text { spreading }\end{array}$ & $\begin{array}{l}\text { Convex, thick, } \\
\text { wrinkled }\end{array}$ & $\begin{array}{l}\text { Convex, thin, slightly } \\
\text { wrinkled, spreading }\end{array}$ & Positive \\
\hline C-14919(N-2001) & Convex, thin, spreading & $\begin{array}{l}\text { Convex, thin, slightly } \\
\text { wrinkled, spreading }\end{array}$ & $\begin{array}{l}\text { Convex, thin, slightly } \\
\text { wrinkled, spreading }\end{array}$ & Positive \\
\hline IMRU 3971 & Flat, slightly thick & Leathery, thick & $\begin{array}{l}\text { Roughened, slightly } \\
\text { raised }\end{array}$ & Negative \\
\hline
\end{tabular}


bonucleic acids. The deoxyribonucleic acid contains $71 \pm 1 \mathrm{~mol} \%$ guanine plus cytosine.

Type strain. The type strain is strain C15003(N-1) (= IFO 13726 = FERM-P $3992=$ ATCC 31281). Another strain, strain C-14919(N2001) $(=$ IFO 13723 = FERM-P $3991=$ ATCC 31280), also has been deposited in culture collections.

A. pretiosum subsp. auranticum subsp. nov. (au.ran' ti.cum, L. adj. auranticum orange). The characteristics of this subspecies are similar to those of the subspecies described above. However, A. pretiosum subsp. auranticum differs from $A$. pretiosum subsp. pretiosum in the following properties: the production of distinctive yellowish orange or orange vegetative growth on various agar media, different colony textures on tryptone-yeast extract agar and peptone-yeast extract-iron agar, and different antagonistic products.

Type strain. The type strain is strain C14482(N-1001) $(=$ IFO $13725=$ FERM-P $4130=$ ATCC 31309).

\section{ACKNOWLEDGMENTS}

We thank H. A. Lechevalier, Waksman Institute of Microbiology, Rutgers, The State University, Piscataway, N.J., for critically reading the manuscript and providing $\boldsymbol{A}$. mirum IMRU 3971 and I. Yano, Department of Bacteriology, Niigata University School of Medicine, Niigata, Japan, for his kind gift of mycolic acid. We also thank E. Ohmura for his encouragement. The technical assistance of $S$. Iinuma is gratefully acknowledged.

\section{LITERATURE CITED}

1. Arai, T., and Y. Mikami. 1972. Chromogenicity of Streptomyces. Appl. Microbiol. 23:402-406.

2. Becker, B., M. P. Lechevalier, and H. A. Lechevalier. 1965. Chemical composition of cell-wall preparations from strains of various form-genera of aerobic actinomycetes. Appl. Microbiol. 13:236-243.

3. Couch, J. N. 1963. Some new genera and species of the Actinoplanaceae. J. Elisha Mitchell Sci. Soc. 79:53-70.

4. Gordon, M. A. 1964. The genus Dermatophilus. J. Bacteriol. 88:509-522.

5. Gordon, R. E., D. A. Barnett, J. E. Handerhan, and C. HorNay Pang. 1974. Nocardia coeliaca, Nocardia autotrophica, and the nocardin strain. Int. J. Syst. Bacteriol. 24:54-63.

6. Hasegawa, T., M. P. Lechevalier, and H. A. Lechevalier. 1978. New genus of the Actinomycetales: Actinosynnema gen. nov. Int. J. Syst. Bacteriol. 28:304-310.

7. Higashide, E., M. Asai, K. Ootsu, S. Tanida, Y. Kosai, T. Hasegawa, T. Kishi, Y. Sugino, and M. Yoneda. 1977. Ansamitocin, a group of novel maytansinoid antibiotics with antitumor properties from Nocardia. Nature (London) 270:721-722.

8. Jacobson, E., W. C. Grauville, and C. E. Frogs. 1958. Color harmony manual, 4 th ed. Container Corporation of America, Chicago, III.

9. Kesters, K., and J. De Ley. 1971. Enzymic tests with resting cells and cell-free extracts, p. 33-52. In J. R. Norris and D. W. Ribbons (ed.), Methods in microbiology, vol. 6A. Academic Press, Inc., New York.

10. Lechevalier, M. P. 1968. Identification of aerobic actino- mycetes of clinical importance. J. Lab. Clin. Med. 71:934-944.

11. Lechevalier, M. P., and H. A. Lechevalier. 1957. A new genus of the Actinomycetales: Waksmania gen. nov. J. Gen. Microbiol. 17:104-111.

12. Lechevalier, M. P., and H. A. Lechevalier. 1970. Chemical composition as a criterion in the classification of aerobic actinomycetes. Int. J. Syst. Bacteriol. 20:435-443.

13. Lechevalier, M. P., H. A. Lechevalier, and A. C. Horan. 1973. Chemical characteristics and classification of nocardiae. Can. J. Microbiol. 19:965-972.

14. Luedemann, G. M. 1968. Geodermatophilus, a new genus of the Dermatophilaceae. J. Bacteriol. 96:1848-1858.

15. Marmur, J. 1961. A procedure for the isolation of deoxyribonucleic acid from microorganisms. J. Mol. Biol. 3:208-218.

16. McClung, N. M. 1974. Family VI. Nocardiaceae Castellani and Chalmers 1919,1040 , p. 726-747. In R. E. Buchanan and N. E. Gibbons (ed.), Bergey's manual of determinative bacteriology, 8th ed. The Williams \& Wilkins Co., Baltimore.

17. Minnikin, D. E., L. Alshamaony, and M. Goodfellow. 1975. Differentiation of Mycobacterium, Nocardia, and related taxa by thin-layer chromatographic analysis of whole-organism methanolysates. J. Gen. Microbiol. 88:200-204.

18. Muroi, M., M. Izawa, Y. Kosai, and M. Asai. 1980. Macbecins I and II, new antitumor antibiotics. II. Isolation and characterization. J. Antibiot. 33:205-212.

19. Paik, G., and M. T. Suggs. 1974. Reagents, stains and miscellaneous test procedures, p. 930-950. In E. H. Lenette, E. H. Spaulding, and J. P. Truant (ed.), Manual of clinical microbiology, 2nd ed. American Society for Microbiology, Washington, D.C.

20. Pridham, T. G., and G. Gottlieb. 1948. The utilization of carbon compounds by some Actinomycetales as an aid for species determination. J. Bacteriol. 56:107-114.

21. Shirling, E. B., and D. Gottlieb. 1966. Method for classification of Streptomyces species. Int. J. Syst. Bacteriol. 16:313-340.

22. Šuput, J., M. P. Lechevalier, and H. A. Lechevalier. 1967. Chemical composition of variants of aerobic actinomycetes. Appl. Microbiol. 15:1356-1361.

23. Tanida, S., K. Haibara, and M. Asai. 1980. Production of tomaymycin by an ansamitocin producing organism. $\mathrm{J}$. Takeda Res. Lab. 39:138-139.

24. Tanida, S., T. Hasegawa, K. Hatano, E. Higashide, and M. Yoneda. 1980. Ansamitocins, maytansinoid antitumor antibiotics. Producing organism, fermentation and antimicrobial activities. J. Antibiot. 33:192-198.

25. Tanida, S., T. Hasegawa, and E. Higashide. 1980. Macbecins I and II, new antitumor antibiotics. Producing organism, fermentation and antimicrobial activities. J. Antibiot. 33:199-204.

26. Tanida, S., T. Hasegawa, M. Muroi, and E. Higashide. 1980. Dnacins, new antibiotics. I. Producing organism, fermentation, and antimicrobial activities. J. Antibiot. 33:1443-1448

27. Tanida, S., M. Izawa, and T. Hasegawa. 1981. Ansamitocin analogs from a mutant strain of Nocardia. I. Isolation of the mutant, fermentation and antimicrobial properties. J. Antibiot. 34:489-495.

28. Thiemann, J. E., and G. Beretta. 1968. A new genus of the Actinoplanaceae: Planobispora gen. nov. Arch. Mikrobiol. 62:157-166.

29. Thiemann, J. E., H. Pagani, and G. Beretta. 1967. A new genus of the Actinomycetaceae: Planomonospora gen. nov. G. Microbiol. 15:27-38.

30. Vera, H. D., and M. Dumoff. 1974. Culture media, p. 881929. In E. H. Lennette, E. H. Spaulding, and J. P. Truant (ed.), Manual of clinical microbiology, 2 nd ed. American Society for Microbiology, Washington, D.C.

31. Waksman, S. A. 1961. The actinomycetes, vol. 2. The Williams \& Wilkins Co., Baltimore. 